\title{
Interactive Effect of Forage Mixing Rates and Organic Fertilizers on the Yield and Nutritive Value of Berseem Clover (Trifolium alexandrinum L.) and Annual Ryegrass (Lolium multiflorum Lam.)
}

\author{
Heba Sabry Attia Salama \\ Crop Science Department, Faculty of Agriculture, Alexandria University, Alexandria, Egypt \\ Email: heba1942001@yahoo.com
}

Received 11 March 2015; accepted 6 April 2015; published 9 April 2015

Copyright (C) 2015 by author and Scientific Research Publishing Inc.

This work is licensed under the Creative Commons Attribution International License (CC BY). http://creativecommons.org/licenses/by/4.0/

(c) (i) Open Access

\begin{abstract}
Berseem clover (Trifolium alexandrinum L.) is the main winter forage legume in Egypt. Despite that the yield and protein content of berseem clover are high, it is characterized by low dry matter content especially in the $1^{\text {st }}$ cut. Intercropping berseem clover with forage grasses, especially annual ryegrass (Lolium multiflorum Lam.) is a recommended technique to produce higher forage yield with better balanced nutritional quality. However, little is known about the performance of these proposed mixtures under the arising organic farming system in Egypt. Organic farming and the application of organic fertilizers (compost and poultry manure) are receiving increased attention in the last few years. Thus, the current study was carried out on the winter season of two successive years (2012 and 2013) in the experimental station of SEKEM organic farm, Egypt. Main aim was to investigate the variation in $1^{\text {st }}$ cut forage yield and nutritive value of berseem clover and annual ryegrass, grown in pure stands and with three mixing rates, under three organic fertilization regimes (compost, poultry litter, and no fertilization). Nutritive value was judged through investigating the crude protein (CP), total carbohydrates (TC), and fiber fractions (NDF, ADF, and ADL). Results revealed significant two-way interaction between the forage treatments and the fertilization regimes for all the studied parameters. In general, mixing berseem clover with annual ryegrass, fertilized by compost or poultry litter resulted in significantly higher forage yield, dry matter content, and balanced $\mathrm{CP}$, TC, and fiber fractions, compared to the pure stands.
\end{abstract}

\section{Keywords}

Forage Mixture, Berseem Clover, Annual Ryegrass, Organic Fertilization

How to cite this paper: Salama, H.S.A. (2015) Interactive Effect of Forage Mixing Rates and Organic Fertilizers on the Yield and Nutritive Value of Berseem Clover (Trifolium alexandrinum L.) and Annual Ryegrass (Lolium multiflorum Lam.). Agricultural Sciences, 6, 415-425. http://dx.doi.org/10.4236/as.2015.64041 


\section{Introduction}

Berseem clover (Trifolium alexandrinum L.) is the most important forage legume crop in Egypt and some of the world countries, particularly those having long winter season with cold-moderate temperature. It is grown either in monoculture or together with different grasses such as ryegrass, barley and oat [1]. Despite that the yield and protein content of berseem clover are high, it is characterized by low dry matter content especially in the $1^{\text {st }}$ cut. Thus, intercropping berseem clover with forage grasses is a low input technology that has many useful effects on the forage's productivity and nutritive value [2] [3]. Choosing favorable mixtures scores several advantages, i.e. yields of mixtures tend to be greater compared with legume or grass alone. Also, legumes supply nitrogen to legume-grass mixtures so it may produce more forage yield than grasses grown alone. The yield of grasses in such mixtures may be greater than its yield when grown in pure stands. Grasses in legume mixtures also contain a higher percentage of protein. Mixtures of grasses and legumes provide a useful model for a better quality diet for animals. The successful mixture needs to be selected from these forage crops that possess compatible maturity and harvesting schemes, complement each other in growth distribution and ecological niche, and do not, severely, compete with each other for growth and life requirements [1] [4]-[6]. The mixture of ryegrass (Lolium multiflorum Lam.) with berseem clover was proposed to fulfill all these requirements [7]. It was then reported that the mixture of ryegrass and berseem clover produced the most superior yield and quality than each of them individually [8] [9]. Thus, berseem clover and annual ryegrass may have a potential as annual mixtures under the Egyptian conditions. However, in order to have a balanced nutritional diet for animal, optimum mixing rate should be used [10]. Optimum seeding rate in the mixture depends mainly on some factors, as the percentage of seed germination per each crop in the mixture, seedling vigor and size of the mature plants. In general, seeding rates of individual species are reduced when combined in mixtures, but the total seeding rate of the mixture may be higher, compared to the pure planting of each. [7] indicated that, when proper mixing rate is used, the mixture significantly out yielded berseem in pure stands.

Integrating composts and manures from different animal and plant sources into livestock systems that use legume-grass forage mixtures has been proved to have positive impact on soil productivity and physical properties [11] [12], which will be positively reflected on forage crop yield and quality [13] [14]. However, to insure these benefits, poultry litter and manure should be applied with certain amounts and at specific intervals during the crop growth period [15], otherwise, the long term, incautious application might result in accumulation of nutrients in the soil [16] and their loss into ground or surface water [17] which will lead to poor water quality and contribute to the environmental pollution [11]. Even though there are major concerns with manure nutrient losses to ground and surface waters, manure nutrients and decaying organic matter are natural components of the environment. Forage production removes and recycles more nutrients from the soil than other crop alternatives, especially when plants of high nutrient value for cattle are appropriately removed to capture this value. Efficient production of forage, using animal manure, strengthens the economic position of the region for ruminant production and limits the potential negative impact of animal agriculture on the environment [18]. Moreover, poultry litter and compost, may be an economical alternative to commercial fertilizer for forage producers as the number of confined animal feeding operations increases and commercial fertilizer prices rise [19].

The current study was conducted to introduce annual legume-grass mixtures for high yield and quality forage production within organic farming systems under the Egyptian conditions. Main aim was to determine the optimum mixing rate for berseem clover-annual ryegrass mixture under different organic fertilization regimes.

\section{Materials and Methods}

\subsection{Site Description}

Field experiments were conducted during the winter seasons of two successive years (2012-2013) at SEKEM organic experimental farm. The farm is characterized by its semi-desert land and located near the town of Belbeis, 60 kilometres north-east of Cairo, Egypt. Mechanical and chemical analyses of the experimental soil are presented in Table 1 and Table 2, respectively.

\subsection{Experimental Design and Treatments}

A split plot experimental design, with three replicates, was used to evaluate 2 cultivars and 3 mixtures under two organic fertilization regimes and a control treatment (no fertilizer). Main plots were assigned to test the organic 
Table 1. Mechanical analysis of the experimental soil.

\begin{tabular}{|c|c|c|c|c|c|c|c|c|}
\hline Humus \% & $\begin{array}{c}\text { CEC } \\
\text { mmolc } \cdot \mathrm{kg}^{-1}\end{array}$ & $\begin{array}{c}\text { Base saturation } \\
\text { \%CEC }\end{array}$ & $\mathrm{pH}$ & $\mathrm{CaSO}_{4} * 2 \mathrm{H}_{2} \mathrm{O}$ & $\mathrm{CaCO}_{3}$ & E.C. $\mathrm{dS} \cdot \mathrm{m}^{-1}$ & TSS ppm & $\begin{array}{l}\text { Bulk density } \\
\mathrm{kg} \cdot \mathrm{m}^{3}\end{array}$ \\
\hline 1.3 & 71 & 100 & 7.8 & 950 & 5.5 & 3.3 & 2112 & 1204.4 \\
\hline
\end{tabular}

Table 2. Macro- and micro-nutrients availability in the experimental soil in $\mathrm{kg} \cdot \mathrm{ha}^{-1}$.

\begin{tabular}{ccccccccc}
\hline Organic matter \% & $\mathrm{C}$ & $\mathrm{N}$ & $\mathrm{P}$ & $\mathrm{S}$ & $\mathrm{Ca}$ & $\mathrm{Mg}$ & $\mathrm{K}$ \\
\hline 0.7 & 21,900 & 2250 & 211 & 272 & 1660 & 350 & 1065 \\
\hline
\end{tabular}

fertilizer applications, namely; compost, poultry litter, and no fertilization. Compost was produced in open windrows and sourced mainly from animal manure (35\%) and plant residues (65\%). Whereas, poultry litter was prepared from pure chicken manure. The 5 forage treatments, tested in the subplots, were: $100 \%$ berseem clover (Trifolium alexandrinum L.), 100\% annual ryegrass (Lolium multiflorum Lam.), 50\% berseem clover $+50 \%$ annual ryegrass, $70 \%$ berseem clover $+30 \%$ annual ryegrass, and $30 \%$ berseem clover $+70 \%$ annual ryegrass. All the forage treatments were drilled with the recommended seeding rates by the Egyptian ministry of agriculture, amounting to $40 \mathrm{~kg} \cdot \mathrm{ha}^{-1}$ for both the berseem clover and annual ryegrass.

\subsection{Management and Sampling}

The experimental plots were sown on $17^{\text {th }}$ and $20^{\text {th }}$ of October in 2012 and 2013, respectively. The plot size was $3 \times 2.4 \mathrm{~m}$. All plots were treated similarly, i.e. fertilized and harvested four times at the same interval in each growing season.Fertilizer applications were added at the rate of 8 ton $\mathrm{ha}^{-1}$, split into 4 equal applications, applied before the first, second, third and fourth harvests. Broadleaf and grass weeds were hand-removed from plots and no serious incidence of insects or diseases was observed. Berseem clover seeds were inoculated by Rhizobium trifolii, commercially produced by the Ministry of Agriculture, Egypt, to encourage biological $\mathrm{N}_{2}$ fixation. Harvesting of plots was carried out from end of November to end of March each year. Plots were manually harvested with a garden cheers to a 5-cm stubble height and the fresh herbage per plot was weighed in the field. A representative sub-sample of approximately $300 \mathrm{~g}$ fresh matter per plot was dried at $60^{\circ} \mathrm{C}$ until constant weight to determine the dry matter (DM) content.

\subsection{Analytical Procedure}

The dried sub-samples were uniformly ground to a particle size of 1-mm. The concentrations of neutral detergent fiber (NDF), acid detergent fiber (ADF) and acid detergent lignin (ADL) were determined sequentially using the semiautomatic ANKOM ${ }^{220}$ Fiber Analyzer (ANKOM Technology, Macedon, NY, USA) as described by [20]. NDF and ADF were analyzed without a heat stable amylase and expressed inclusive of residual ash, while ADL content was corrected after the residual ash content. Ash was determined by combusting the sub-sample in a muffle oven at $550^{\circ} \mathrm{C}$ for $3 \mathrm{~h}$ [21]. Prior to total nitrogen analysis, the dried samples were ground again to a particle size of $10 \mu \mathrm{m}$. The nitrogen content was traditionally analyzed by the Kjeldahl procedure [21], and crude protein (CP) content was calculated from the $\mathrm{N}$ content $(\mathrm{CP}=\mathrm{N} \times 6.25)$. Total carbohydrate content (TC) was determined using the phenol-sulfuric acid method as described by [22].

\subsection{Statistical Analysis}

The forage treatments, fertilizer applications as well as their interactions were tested for significance using Proc Mixed of SAS 9.1 [23]. Data from the 2012 and 2013 growing seasons are presented in a combined analysis, because the test of homogeneity of variance [24], when performed, revealed that the error of the variance between the two experimental seasons was not significantly different.

The yield data $(Y)$ and the nutritive parameters $(P)$ were then analyzed according to the following model:

$$
Y_{i j k} / P_{i j k}=\mu+T_{i}+F_{j}+R_{k}+e_{i k}+(T \times F)_{i j}+s_{i j k}
$$

where $\mu$ is the overall mean, $T_{i}$ is the forage treatment effect $(i=1,2,3,4,5), F_{j}$ is the fertilizer regime effect 
$(j=1,2,3), R_{k}$ is the replication $(k=1,2,3), e_{i j k}$ is the effect of main plot, $(T \times F)_{i j}$ is the effect of the interaction between the forage treatment and fertilizer regime, and $s_{i j k}$ is the effect of sub-plot.

First cut yield and quality data are presented and discussed. Significance was declared at $P<0.05$ and means were compared with the least significant difference procedure and probabilities were adjusted using BonferroniHolm test [25].

\section{Results and Discussion}

The analysis of variance revealed a significant two-way interaction among forage treatments and fertilizer applications on the first cut fresh yield (ton $\left.\cdot \mathrm{ha}^{-1}\right)$, DM content $\left(\mathrm{g} \cdot \mathrm{kg}^{-1}\right)$ and all the investigated quality parameters. Similar findings were reported by [26].

\subsection{Fresh Yield ton $\cdot \mathrm{ha}^{-1}$}

Results of the $1^{\text {st }}$ cut fodder yield, presented in Table 3 and Figure 1, reveal that the forage mixture $70 \%$ berseem clover $+30 \%$ annual ryegrass followed by the mixture $50 \%$ berseem clover $+50 \%$ annual ryegrass produced the highest $1^{\text {st }}$ cut yields amounting to 10.22 and 9.45 ton ha ${ }^{-1}$, respectively, in average for the three fertilization regimes. This result highlights the hypothesised advantage of the legume-grass mixtures in increasing

Table 3. Means of the $1^{\text {st }}$ cut fresh yield (ton $\cdot \mathrm{ha}^{-1}$ ) and dry matter content $\left(\mathrm{g} \cdot \mathrm{kg}^{-1}\right)$ as affected by the forage treatment $\mathrm{x}$ fertilization regime interaction.

\begin{tabular}{|c|c|c|c|c|c|c|}
\hline \multirow{3}{*}{ Forage Treatment } & \multicolumn{3}{|c|}{ Fresh Yield (ton $\cdot$ ha $^{-1}$ ) } & \multicolumn{3}{|c|}{ Dry matter content $\left(\mathrm{g} \cdot \mathrm{kg}^{-1}\right)$} \\
\hline & \multicolumn{3}{|c|}{ Fertilizer Treatment } & \multicolumn{3}{|c|}{ Fertilizer Treatment } \\
\hline & Control & Compost & Poultry litter & Control & Compost & Poultry litter \\
\hline Pure berseem clover & $7.50 \mathrm{bB}^{*}$ & $8.77 \mathrm{aB}$ & $9.00 \mathrm{aB}$ & $91.38 \mathrm{bC}$ & $110.29 \mathrm{aD}$ & $108.15 \mathrm{aC}$ \\
\hline Pure annual ryegrass & $6.09 \mathrm{aC}$ & $7.00 \mathrm{aC}$ & $7.79 \mathrm{aC}$ & $165.85 \mathrm{cA}$ & $200.04 \mathrm{aA}$ & $175.85 \mathrm{bA}$ \\
\hline $50 \%$ berseem: $50 \%$ ryegrass & $8.00 \mathrm{bAB}$ & $9.80 \mathrm{aAB}$ & $10.55 \mathrm{aA}$ & $117.70 \mathrm{bB}$ & $135.29 \mathrm{aC}$ & $140.10 \mathrm{aB}$ \\
\hline $70 \%$ berseem: $30 \%$ ryegrass & $9.13 \mathrm{bA}$ & $10.85 \mathrm{aA}$ & $10.67 \mathrm{aA}$ & $121.95 \mathrm{aB}$ & $126.55 \mathrm{aC}$ & $131.80 \mathrm{aB}$ \\
\hline $30 \%$ berseem:70\% ryegrass & $4.19 \mathrm{aD}$ & $5.22 \mathrm{aD}$ & $5.37 \mathrm{aD}$ & $151.45 \mathrm{bA}$ & $152.77 \mathrm{bB}$ & $168.55 \mathrm{aA}$ \\
\hline L.S.D $D_{0.05}$ & \multicolumn{3}{|c|}{1.20} & \multicolumn{3}{|c|}{15.00} \\
\hline
\end{tabular}

*Means followed by different small letter(s) within the same row or different capital letter(s) within the same column, for each parameter, are significantly different according to the LSD test at 0.05 level of probability.

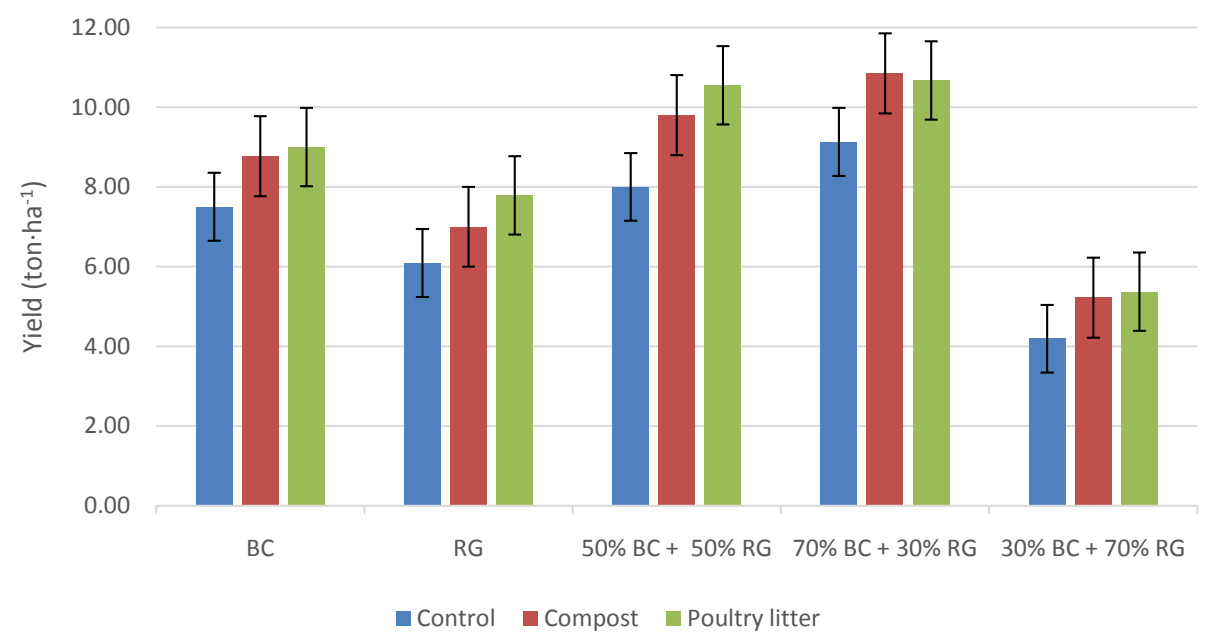

Figure 1. Variations in yield (ton $\cdot \mathrm{ha}^{-1}$ ) as affected by the interaction between forage treatments and organic fertilizer applications. $\mathrm{BC}=$ Berseem clover, $\mathrm{RG}=$ Ryegrass. 
the forage yield. These results support and confirm the findings of [1], who stated that mixing the berseem clover with ryegrass with the ratio $75: 25 \%$ or 50:50\% produced the highest fresh and dry forage yields, when compared to other mixing rates. On the other hand, the mixture $30 \%$ berseem clover $+70 \%$ annual ryegrass produced the lowest significant $1^{\text {st }}$ cut yield, around 4.93 ton $\cdot \mathrm{ha}^{-1}$, in average of the three fertilization regimes. Comparing the sole berseem clover to the sole annual ryegrass, it was found that the pure legume stands produced better yields than the pure grass stands. This result was in good accordance with the findings of many researchers e.g. [2] [3] [27]-[29]. Application of the compost and poultry litter resulted in significantly increasing the $1^{\text {st }}$ cut yield compared to the control treatment in case of the sole berseem clover, $50 \%$ berseem clover $+50 \%$ annual ryegrass and $70 \%$ berseem clover $+30 \%$ annual ryegrass. This might be attributed to the correction of $\mathrm{N}$ deficiency and, thus, improved soil properties upon poultry litter and compost application [15] [30] [31]. Similar, increase in yields of $1^{\text {st }}$ cut timothy-red clover, forage maize, bermudagrass, sorghum and annual ryegrass swards upon compost/poultry litter applications relative to the control were reported [19] [32]-[35].

\subsection{Dry Matter (DM) Content g·kg-1}

The sole annual ryegrass produced the highest significant DM content $\left(\mathrm{g} \cdot \mathrm{kg}^{-1}\right)$, especially when fertilized by the compost and poultry litter, values were 200.04 and $175.85 \mathrm{~g} \cdot \mathrm{kg}^{-1}$, respectively (Table 3, Figure 2). The second superior forage treatment was the mixture $30 \%$ berseem clover $+70 \%$ annual ryegrass, with $168.55 \mathrm{~g} \mathrm{DM} \mathrm{kg}{ }^{-1}$ when treated by poultry litter. While, on the contrary, the sole berseem clover produced the lowest significant DM content $\left(\mathrm{g} \cdot \mathrm{kg}^{-1}\right)$ amounting to $91.38 \mathrm{~g} \cdot \mathrm{kg}^{-1}$ when no fertilizer was applied and 110.29 and $108.15 \mathrm{~g} \cdot \mathrm{kg}^{-1}$ when compost and poultry litter were applied, respectively. Similar results were reported for clover-barley and clover-triticale stands [3] [28] [29].

\subsection{Crude Protein (CP) Content g•kg-1}

The significant effect of forage $\times$ fertilization interaction on the CP content is presented in Table 4 and Figure 3 . Sole berseem clover treated by compost and poultry litter accumulated the highest significant CP content, amounting to 199.05 and $197.95 \mathrm{~g} \cdot \mathrm{kg}^{-1}$, respectively. This was, obviously, followed by the mixture $70 \%$ berseem clover $+30 \%$ annual ryegrass with 181.89 and $185.01 \mathrm{~g} \mathrm{CP} \mathrm{kg}^{-1}$ for the same fertilizer treatments, respectively. The lowest significant protein content was a character of the sole annual ryegrass and the forage mixture $30 \%$ berseem clover $+70 \%$ annual ryegrass. These results were in line with the results of [14] who suggested that the legume component (equal or more than 30\%) of the binary legume-grass mixture acted as an effective "N-buffer" maintaining forage yield and protein content consistently higher, and within a narrower range across all treatments. [1] [36]-[38] came to similar observations. They found that planting of pure berseem clover and its mixtures with the highest seeding rates recorded the highest protein percentages. Concerning the fertilizer regimes, the compost and poultry litter applications significantly increased the forage concentration of CP. Similar results

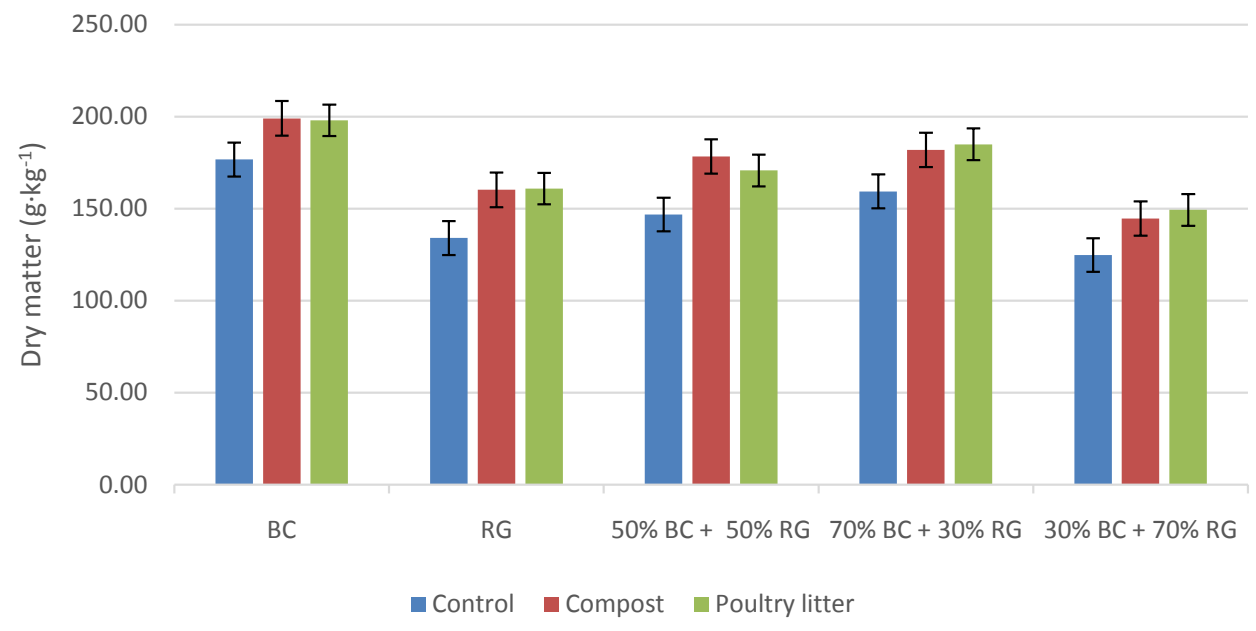

Figure 2. Variations in dry matter content $\left(\mathrm{g} \cdot \mathrm{kg}^{-1}\right)$ as affected by the interaction between forage treatments and organic fertilizer applications. $\mathrm{BC}=$ Berseem clover, $\mathrm{RG}=$ Ryegrass. 
Table 4. Means of the $1^{\text {st }}$ cut crude protein and total carbohydrates contents $\left(\mathrm{g} \cdot \mathrm{kg}^{-1}\right.$ ) as affected by the forage treatment $\mathrm{x}$ fertilization regime interaction.

\begin{tabular}{ccccccc}
\hline & \multicolumn{3}{c}{ Crude protein $\left(\mathrm{g} \cdot \mathrm{kg}^{-1}\right)$} & \multicolumn{3}{c}{ Total carbohydrates $\left(\mathrm{g} \cdot \mathrm{kg}^{-1}\right)$} \\
\cline { 2 - 7 } Forage Treatment & \multicolumn{3}{c}{ Fertilizer Treatment } \\
\cline { 2 - 7 } & Control & Compost & Poultry litter & Control & Compost & Poultry litter \\
\hline Pure berseem clover & $176.70 \mathrm{bA}^{*}$ & $199.05 \mathrm{aA}$ & $197.95 \mathrm{aA}$ & $556.17 \mathrm{bD}$ & $600.46 \mathrm{aC}$ & $589.36 \mathrm{aD}$ \\
Pure annual ryegrass & $134.05 \mathrm{bCD}$ & $160.23 \mathrm{aCD}$ & $160.90 \mathrm{aCD}$ & $804.00 \mathrm{aA}$ & $797.80 \mathrm{aA}$ & $809.10 \mathrm{aA}$ \\
$50 \%$ berseem:50\% ryegrass & $146.80 \mathrm{bBC}$ & $178.35 \mathrm{aBC}$ & $170.75 \mathrm{aBC}$ & $769.07 \mathrm{aB}$ & $780.08 \mathrm{aA}$ & $783.91 \mathrm{aB}$ \\
$70 \%$ berseem:30\% ryegrass & $159.40 \mathrm{bAB}$ & $181.89 \mathrm{aAB}$ & $185.01 \mathrm{aAB}$ & $650.28 \mathrm{bC}$ & $684.66 \mathrm{aB}$ & $668.37 \mathrm{abC}$ \\
30\% berseem:70\% ryegrass & $124.80 \mathrm{aD}$ & $144.66 \mathrm{aD}$ & $149.35 \mathrm{aD}$ & $784.23 \mathrm{aAB}$ & $778.45 \mathrm{aA}$ & $790.11 \mathrm{aAB}$ \\
\hline L.S.D. & & 20.01 & & & 19.80 & \\
\hline
\end{tabular}

*Means followed by different small letter(s) within the same row or different capital letter(s) within the same column, for each parameter, are significantly different according to the LSD test at 0.05 level of probability.

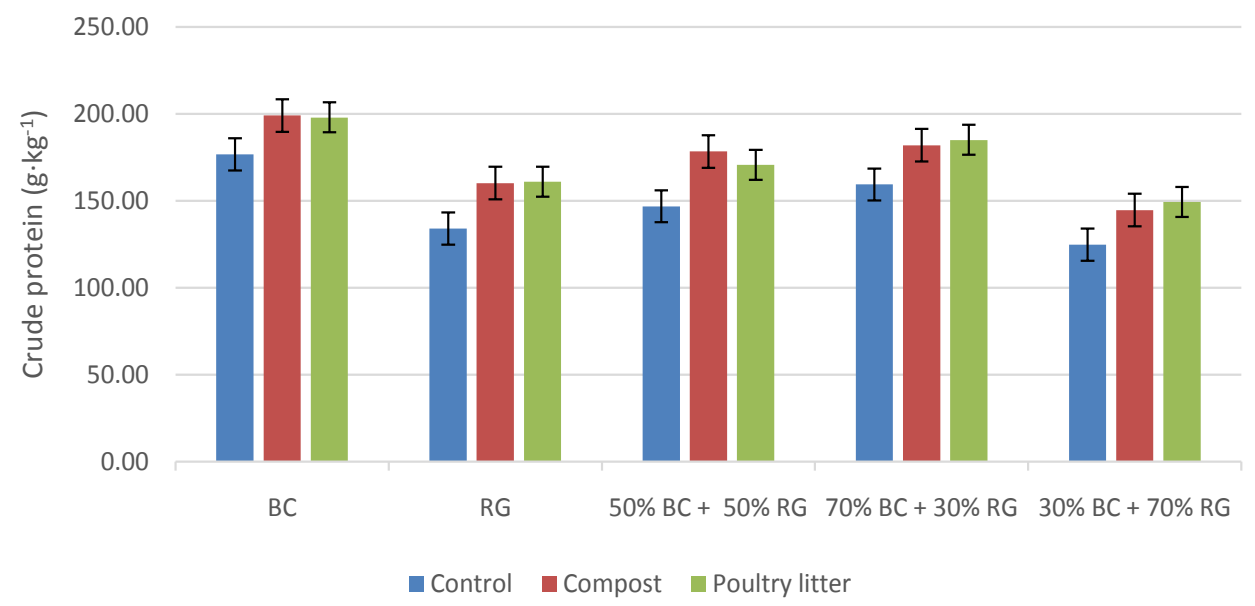

Figure 3. Variations in crude protein content $\left(\mathrm{g} \cdot \mathrm{kg}^{-1}\right)$ as affected by the interaction between forage treatments and organic fertilizer applications. BC = Berseem clover, RG = Ryegrass.

were reported by [16] with tall fescue pastures, [39] for Bermudagrass hay, [35] with annual ryegrass and [40] with forage legume swards. These results confirm that nitrogen concentration in plant tissues increase with poultry litter application. [39], therefore, concluded that fertilizing with poultry litter is an excellent sustainable agricultural method.

\subsection{Total Carbohydrates (TC) Content g•kg-1}

Table 4 and Figure 4 illustrate that the sole annual ryegrass was characterized by its significantly superior TC content, with $803.63 \mathrm{~g} \cdot \mathrm{kg}^{-1}$, in average for the three fertilizer regimes. Also, superior was the forage mixture $30 \%$ berseem clover $+70 \%$ annual ryegrass, with $784.26 \mathrm{~g} \cdot \mathrm{kg}^{-1}$, in average for the three fertilizer regimes. The lowest significant TC content was a character of the sole berseem clover, amounting to $556.17 \mathrm{~g} \cdot \mathrm{kg}^{-1}$ when no fertilizer was applied. Forage legumes are known to have higher protein and cell wall fractions, but lower carbohydrate contents than grasses [36]. [8] indicated that ash and nitrogen free extract were higher and crude protein was lower in mixture in comparison with clover monoculture. While the reverse was true in ryegrass in pure stand. [41] stated that grasses in monoculture or in mixtures with berseem clover, particularly with the lowest seeding rates of berseem clover (25\%) had the superiority for nitrogen free extract contents. [1] observed low nitrogen free extract content with the highest seeding rate (75\%) of berseem clover with several evaluated grasses particularly for the first cut, which they attributed to the vigorous growth of the tested grasses early in the 
season. Noticeably, the forage mixtures $70 \%$ berseem clover $+30 \%$ annual ryegrass and $50 \%$ berseem clover + $50 \%$ annual ryegrass fertilized by compost and poultry litter, produced relatively high CP and TC contents, respectively, which were comparable to the superior forage treatments in both parameters.

\subsection{Fiber Fractions (NDF, ADF and ADL) Contents g.kg-1}

Means of the three investigated fibre fractions as affected by the interaction between the forage and fertilizer treatments are presented in Table 5 and Figure 5, Figure 6 and Figure 7. Data showed that the maximum significant NDF and ADF contents were produced from the sole annual ryegrass under the three fertilization regimes (466.91 $\mathrm{g} \mathrm{NDF} \mathrm{kg}^{-1}$ and $316.36 \mathrm{~g} \mathrm{ADF} \mathrm{kg}^{-1}$, in average) and the forage mixture 50\% berseem clover $+50 \%$ annual ryegrass, especially when fertilized by the compost (465.49 $\mathrm{g} \mathrm{NDF} \mathrm{kg}^{-1}$ and $315.47 \mathrm{~g} \mathrm{ADF} \mathrm{kg}^{-1}$ ). [1]-[41] stated that crude fiber content increased in mixtures than those in pure clover or ryegrass. In his study on the

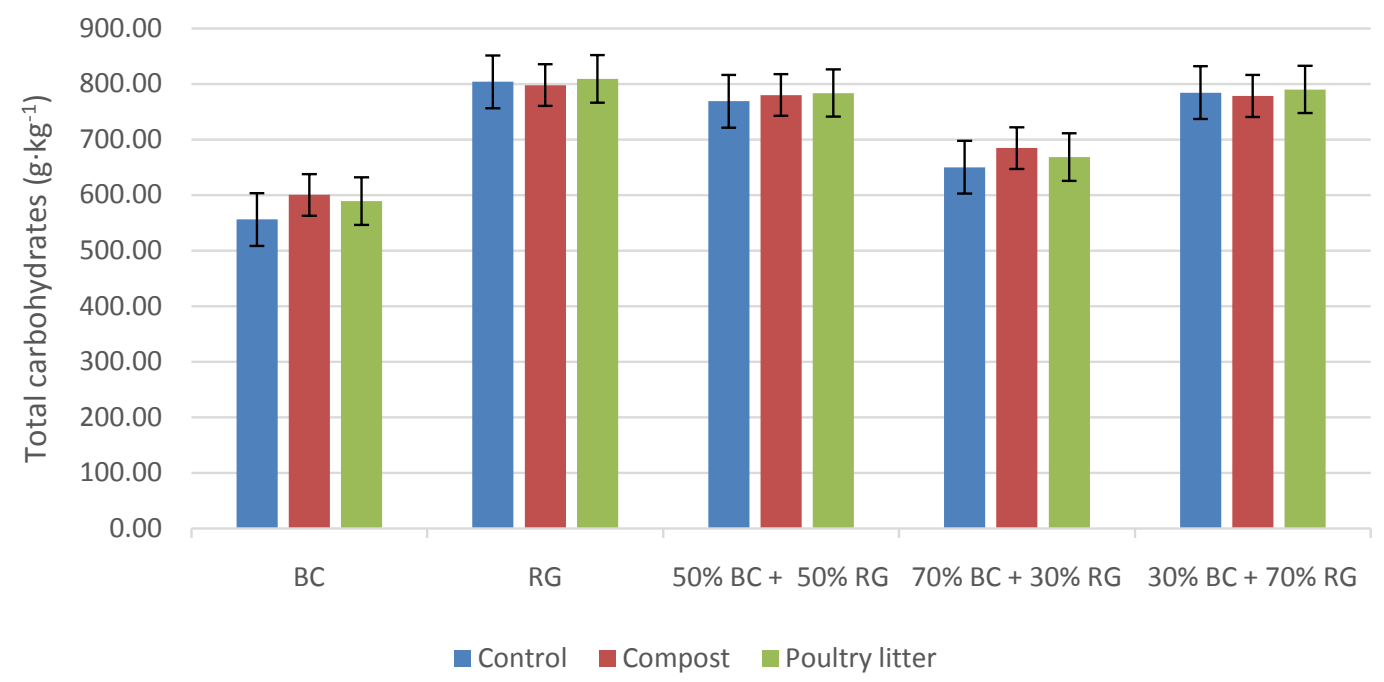

Figure 4. Variations in total carbohydrates content $\left(\mathrm{g} \cdot \mathrm{kg}^{-1}\right)$ as affected by the interaction between forage treatments and organic fertilizer applications. $\mathrm{BC}=$ Berseem clover, $\mathrm{RG}=$ Ryegrass.

Table 5. Means of the $1^{\text {st }}$ cut neutral detergent fibre (NDF), acid detergent fibre (ADF) and acid detergent lignin (ADL) contents $\left(\mathrm{g} \cdot \mathrm{kg}^{-1}\right)$ as affected by the forage treatment $\mathrm{x}$ fertilization regime interaction.

\begin{tabular}{|c|c|c|c|c|c|c|c|c|c|}
\hline \multirow{3}{*}{$\begin{array}{l}\text { Forage } \\
\text { Treatment }\end{array}$} & \multicolumn{3}{|c|}{$\operatorname{NDF}\left(\mathrm{g} \cdot \mathrm{kg}^{-1}\right)$} & \multicolumn{3}{|c|}{$\mathrm{ADF}\left(\mathrm{g} \cdot \mathrm{kg}^{-1}\right)$} & \multicolumn{3}{|c|}{ ADL $\left(\mathrm{g} \cdot \mathrm{kg}^{-1}\right)$} \\
\hline & \multicolumn{3}{|c|}{ Fertilizer Treatment } & \multicolumn{3}{|c|}{ Fertilizer Treatment } & \multicolumn{3}{|c|}{ Fertilizer Treatment } \\
\hline & Control & Compost & Poultry litter & Control & Compost & Poultry litter & Control & Compost & Poultry litter \\
\hline $\begin{array}{l}\text { Pure berseem } \\
\text { clover }\end{array}$ & $399.16 \mathrm{aC}^{*}$ & $426.48 \mathrm{aB}$ & $424.01 \mathrm{aB}$ & $272.04 \mathrm{aB}$ & $276.63 \mathrm{aB}$ & $280.30 \mathrm{aB}$ & $40.90 \mathrm{aA}$ & $37.10 \mathrm{aAB}$ & 39.89 aA \\
\hline $\begin{array}{l}\text { Pure annual } \\
\text { ryegrass }\end{array}$ & $462.82 \mathrm{aA}$ & $462.78 \mathrm{aA}$ & $475.14 \mathrm{aA}$ & $316.91 \mathrm{aA}$ & 312.78 aA & 319.38 aA & $17.42 \mathrm{aC}$ & $19.96 \mathrm{aD}$ & $21.60 \mathrm{aB}$ \\
\hline $\begin{array}{l}50 \% \text { berseem: } \\
50 \% \text { ryegrass }\end{array}$ & $434.82 \mathrm{aAB}$ & $413.80 \mathrm{aB}$ & $420.89 \mathrm{aB}$ & $297.68 \mathrm{aAB}$ & $303.15 \mathrm{aAB}$ & $285.12 \mathrm{aB}$ & $29.30 \mathrm{aB}$ & $30.22 \mathrm{aBC}$ & $33.20 \mathrm{aA}$ \\
\hline $\begin{array}{l}70 \% \text { berseem: } \\
30 \% \text { ryegrass }\end{array}$ & $423.35 \mathrm{bBC}$ & $465.49 \mathrm{aA}$ & $460.81 \mathrm{aA}$ & $296.38 \mathrm{aAB}$ & 315.47 aA & 294.80 аАВ & $39.20 \mathrm{aA}$ & 38.29 aA & $34.81 \mathrm{aA}$ \\
\hline $\begin{array}{l}30 \% \text { berseem: } \\
70 \% \text { ryegrass }\end{array}$ & $416.56 \mathrm{aBC}$ & $412.88 \mathrm{aB}$ & $418.30 \mathrm{aB}$ & $300.67 \mathrm{aAB}$ & $285.78 \mathrm{aAB}$ & $295.97 \mathrm{aAB}$ & $23.12 \mathrm{aBC}$ & $25.75 \mathrm{aCD}$ & $21.91 \mathrm{aB}$ \\
\hline L.S.D $D_{0.05}$ & & 29.00 & & & 30.10 & & & 8.00 & \\
\hline
\end{tabular}

"Means followed by different small letter(s) within the same row or different capital letter(s) within the same column, for each parameter, are significantly different according to the LSD test at 0.05 level of probability. 


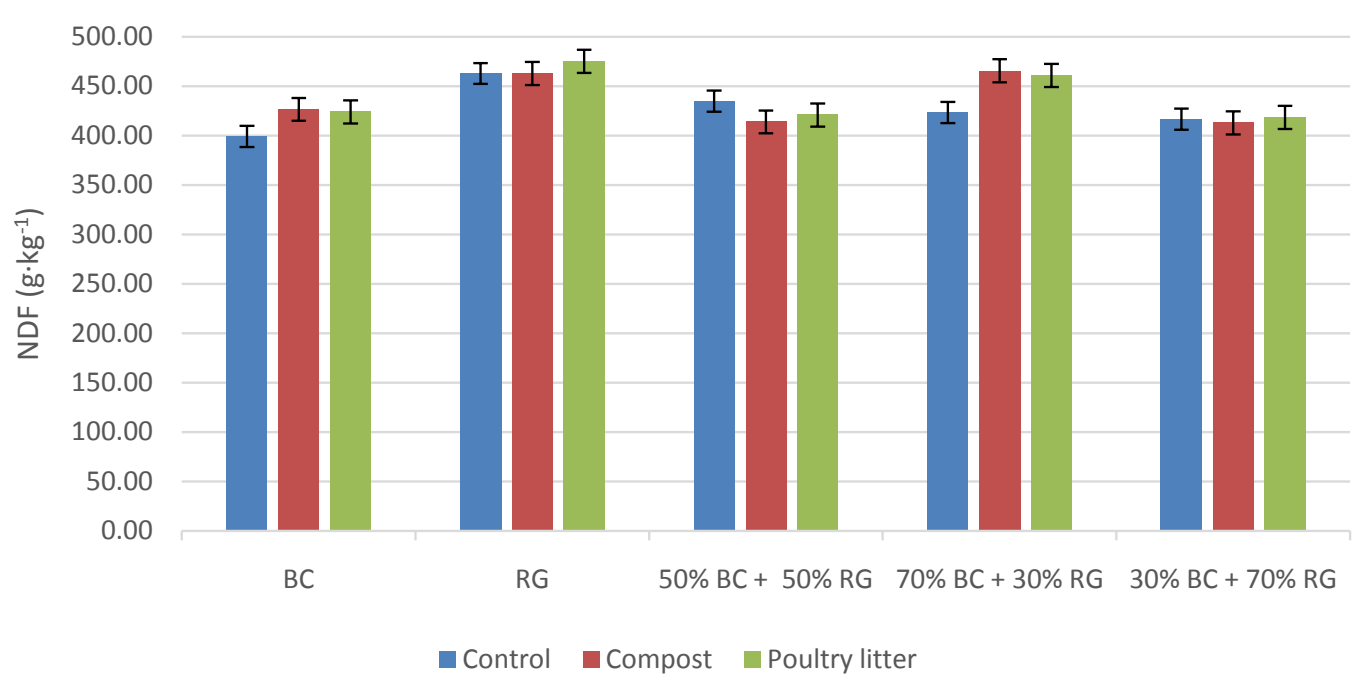

Figure 5. Variations in NDF content $\left(\mathrm{g} \cdot \mathrm{kg}^{-1}\right)$ as affected by the interaction between forage treatments and organic fertilizer applications. $\mathrm{BC}=$ Berseem clover, $\mathrm{RG}=$ Ryegrass.

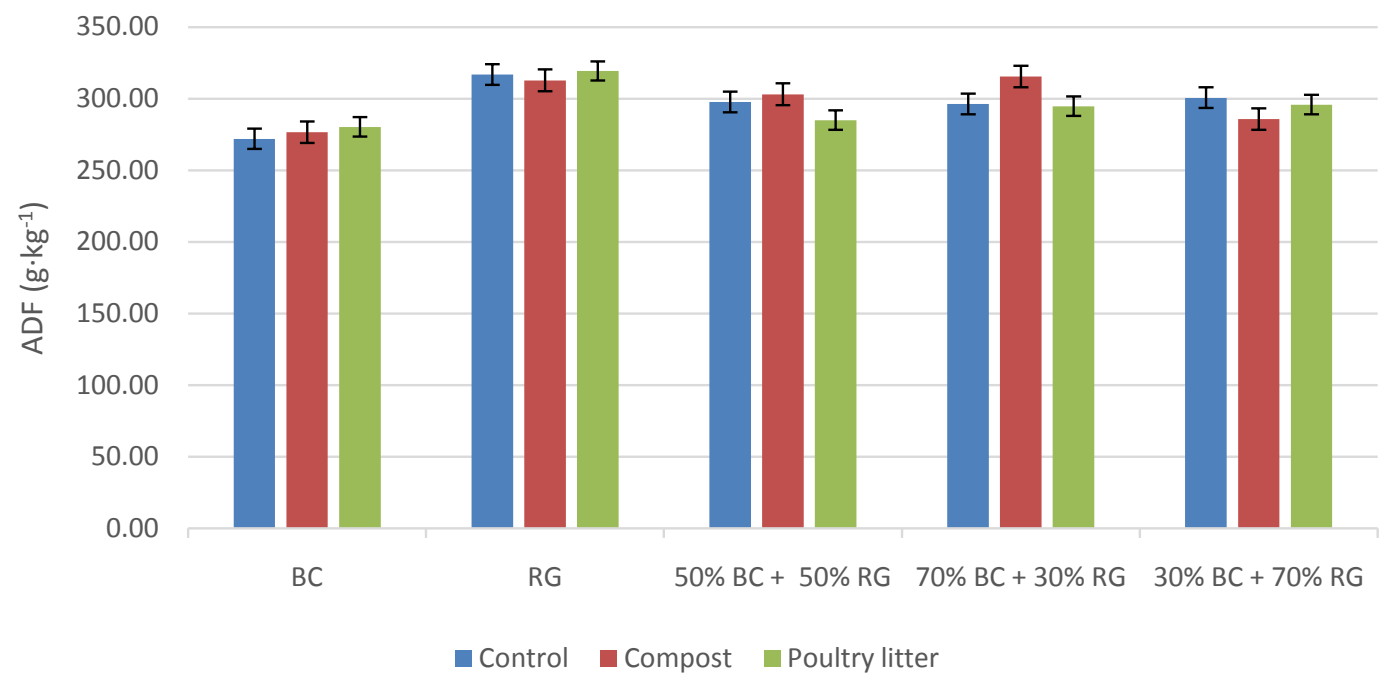

Figure 6. Variations in ADF content $\left(\mathrm{g} \cdot \mathrm{kg}^{-1}\right)$ as affected by the interaction between forage treatments and organic fertilizer applications. $\mathrm{BC}=$ Berseem clover, $\mathrm{RG}=$ Ryegrass.

forage potential of kenaf, [40] reported that the application of compost increased the NDF values. However, similar to the current study, [27] reported insignificant effect of compost application on ADF contents. The sole Berseem clover was inferior in its NDF and ADF contents, with values $416.55 \mathrm{~g} \mathrm{NDF} \mathrm{kg}{ }^{-1}$ and $276.32 \mathrm{~g} \mathrm{ADF}$ $\mathrm{kg}^{-1}$, in average for the three fertilization regimes. In general the differences in NDF and ADF contents for all the tested treatments were $75.98 \mathrm{~g} \cdot \mathrm{kg}^{-1}$ and $47.34 \mathrm{~g} \cdot \mathrm{kg}^{-1}$, respectively. The ADL content followed a slightly different trend than the NDF and ADF, with the sole berseem clover and the mixture $50 \%$ berseem clover $+50 \%$ annual ryegrass recording the highest significant values in average for the three fertilization regimes amounting to 39.30 and $37.43 \mathrm{~g} \mathrm{~kg}^{-1}$, respectively. The lowest ADL content was recorded by the sole annual ryegrass and the mixture $30 \%$ berseem clover $+70 \%$ annual ryegrass, amounting to 19.66 and $23.59 \mathrm{~g} \cdot \mathrm{kg}^{-1}$, respectively, in average for the three fertilizer applications. [42] stated that forage legumes are generally higher in lignin than forage grasses.

\section{Conclusion}

Mixing berseem clover with annual ryegrass with the different ratios significantly improved forage yield and 


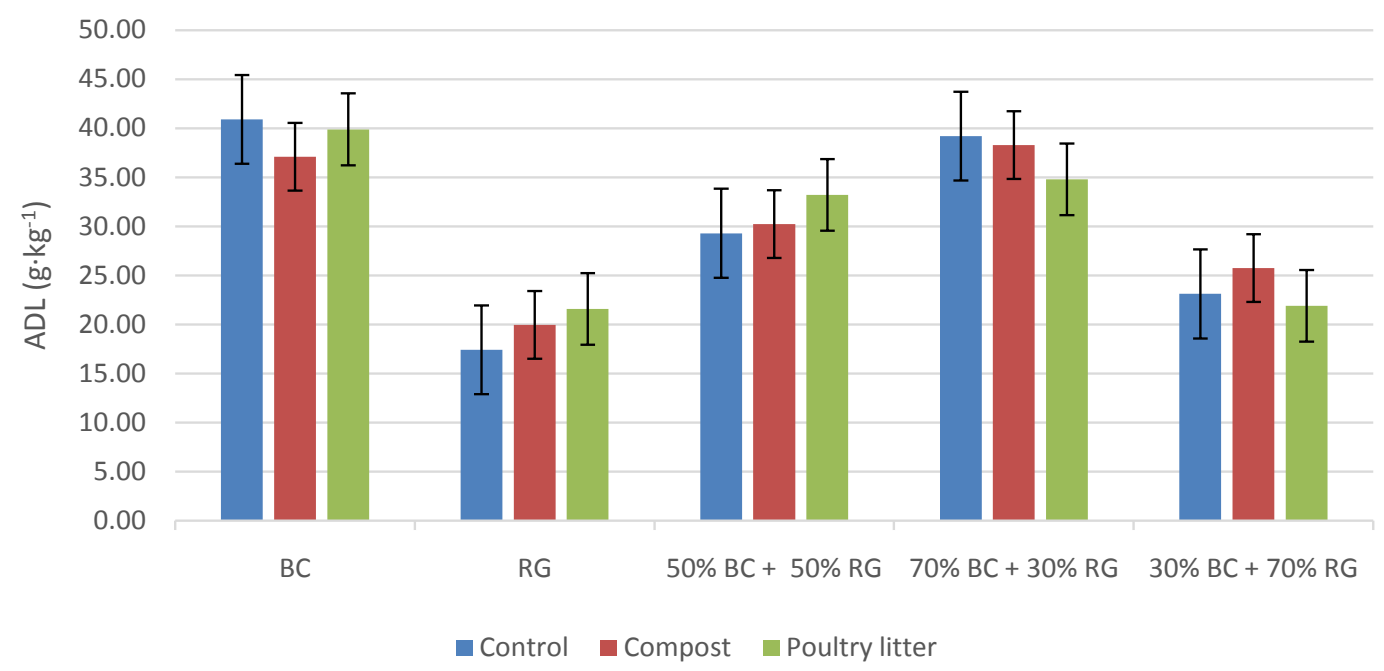

Figure 7. Variations in ADL content $\left(\mathrm{g} \cdot \mathrm{kg}^{-1}\right)$ as affected by the interaction between forage treatments and organic fertilizer applications. $\mathrm{BC}=$ Berseem clover, $\mathrm{RG}=$ Ryegrass .

DM content. Pure berseem stands were superior in the CP content, while, pure ryegrass stands were superior in the TC and fibre fractions. However, when organically fertilized, the forage mixtures gave comparably high CP, TC and fibre fractions. Therefore, the researcher suggests conducting animal feeding trials to examine the response of the ruminants to the forage mixtures.

\section{Acknowledgements}

The author is grateful to Dr. Ibrahim Abouleish, and Mrs. Angela Hofmann at SEKEM-Egypt for providing the experimental site in one of their organic farms. Also for their assistance during the sampling process.

\section{References}

[1] Al-Khateeb, S.A., Leilah, A.A., Al-Thabet, S.S. and Al-Barak, K.M. (2001) Study on Mixed Sowing of Egyptian Clover (Trifolium alexandrinum L.) with Ryegrass (Lolium multiflorum Lam.), Barley (Hordeumvulgare L.) and Oat (Avena fatua L.) on Fodder Yield and Quality. Egyptian Journal of Applied Sciences, 16, 159-171.

[2] Ross, S.M., King, J.R., O’Donovan, J.T. and Spaner, D. (2004) Forage Potential of Intercropping Berseem Clover with Barley, Oat, or Triticale. Agronomy Journal, 96, 1013-1020. http://dx.doi.org/10.2134/agronj2004.1013

[3] El-Karamany, M.F., Bakry, B.A. and Elewa, T.A. (2014) Integrated Action of Mixture Rates and Nitrogen Levels on Quantity and Quality of Forage Mixture from Egyptian Clover and Barley in Sandy Soil. Agricultural Sciences, 5, 1539-1546. http://dx.doi.org/10.4236/as.2014.514165

[4] El-Hattab, A.H., Abou-Raya, A.K., Abdel-Raof, M.S., Kandil, A. and Khalil, N.A. (1982) Forage Yield and Quality of Berseem-Grass Mixtures as Affected by Seeding Rates and Time of Cutting. Bulletin of Faculty of Agriculture, Cairo University, 34, 22-34.

[5] Seif, S.A. and Sedhom, S.A. (1988) Effect of Mixing Cereal Grasses with Fahl Berseem on the Forage Production and Botanical Fractions. Egyptian Journal of Applied Science, 3, 204-216.

[6] Holland, J.P. and Brummer, E.C. (1999) Cultivar Effects on Oat-Berseem Clover Intercrops. Agronomy Journal, 91, 321-329. http://dx.doi.org/10.2134/agronj1999.00021962009100020023x

[7] Rammah, A.M. and Radwan, M.S. (1977) The Influence of Seeding Rate and Cutting Management on Yield and Chemical Composition of Berseem-Grass Mixtures. Journal of Agronomy and Crop Science, 145, 103-111.

[8] Nor El-Din, M.A. (1978) Effect of Berseem-Ryegrass Mixtures on Forage Yield. M.Sc. Thesis, Al-Azhar University, Cairo.

[9] El Said, M. and Sharief, A.E. (1993) Effect of Nitrogen and Phosphorous Fertilization and Seeding Rates of Forage Yields and Quality of Egyptian Clover-Ryegrass Mixtures. Journal of Agricultural Science. Mansoura University, 18, 1335-1341.

[10] Wiersma, D.W., Hoffman, P.C. and Mlynarek, M.J. (1999) Companion Crops for Legume Establishment: Forage Yield, Quality and Establishment Success. Journal of Production Agriculture, 12, 116-122. 
http://dx.doi.org/10.2134/jpa1999.0116

[11] Edmeades, D.C. (2003) The Long-Term Effects of Manures and Fertilisers on Soil Productivity and Quality: A Review. Nutrient Cycling in Agroecosystems, 66, 165-180. http://dx.doi.org/10.1023/A:1023999816690

[12] Lynch, D.H., Voroney, R.P. and Warman, P.R. (2005) Soil Physical Properties and Organic Matter Fractions under Forages Receiving Composts, Manure or Forages. Compost Science and Utilization, 13, 252-261. http://dx.doi.org/10.1080/1065657X.2005.10702249

[13] Sanderson, M.A. and Jones, R.M. (1997) Forage Yields, Nutrient Uptake, Soil Chemical Changes, and Nitrogen Volatilization from Bermudagrass Treated with Dairy Manure. Journal of Production Agriculture, 10, 266-271. http://dx.doi.org/10.2134/jpa1997.0266

[14] Lynch, D.H., Voroney, R.P. and Warman, P.R. (2004) Nitrogen Availability from Composts for Humid Region Perennial Grass and Legume-Grass Forage Production. Journal of Environmental Quality, 33, 1509-1520. http://dx.doi.org/10.2134/jeq2004.1509

[15] Lucero, D.W., Martens, D.C., McKenna, J.R. and Starner, D.E. (1995) Poultry Litter Effects on Unmanaged Pasture Yield, Nitrogen and Phosphorus Uptakes, and Botanical Composition. Communications in Soil Science and Plant Analysis, 26, 861-881. http://dx.doi.org/10.1080/00103629509369340

[16] Kingery, W.L., Wood, C.W., Delaney, D.P., Williams, J.C., Mullins, G.L. and van Santen, E. (2013) Implications of Long-Term Land Application of Poultry Litter on Tall Fescue Pastures. Journal of Production Agriculture, 6, 390-395. http://dx.doi.org/10.2134/jpa1993.0390

[17] Van Wieringen, L.M., Harrison, J.H., Nennich, T., Davidson, D.L., Morgan, L., Chen, S., Bueler, M. and Hoisington, F. (2005) Manure Management Effects on Grass Production, Nutritive Content, and Soil Nitrogen for a Grass SilageBased Dairy Farm. Journal of Environmental Quality, 34, 164-173.

[18] Newton, G.L., Bernard, J.K., Hubbard, R.K., Allison, J.R., Lowrance, R.R., Gascho, G.J., Gates, R.N. and Vellidis, G. (2003) Managing Manure Nutrients through Multi-Crop Forage Production. Journal of Dairy Science, 86, 2243-2252. http://dx.doi.org/10.3168/jds.S0022-0302(03)73815-6

[19] Evers, G.W. (1998) Comparison of Broiler Poultry Litter and Commercial Fertilizer for Coastal Bermudagrass Production in the Southern US. Journal of Sustainable Agriculture, 12, 55-77. http://dx.doi.org/10.1300/J064v12n04_06

[20] Van Soest, P.J., Robertson, J.B. and Lewis, B.A. (1991) Methods for Dietary Fiber, Neutral Detergent Fiber, and Nonstarch Polysaccharides in Relation to Animal Nutrition. Journal of Dairy Science, 74, 3583-3597. http://dx.doi.org/10.3168/jds.S0022-0302(91)78551-2

[21] AOAC (1990) Official Methods of Analysis. 15th Edition, Association of Official Analytical Chemists, Arlington.

[22] DuBois, M., Gilles, K., Hamilton, J., Rebers, P. and Smith, F. (1956) Colorimetric Method for Determination of Sugars and Related Substances. Analytical Chemistry, 28, 350-356. http://dx.doi.org/10.1021/ac60111a017

[23] SAS Institute, Inc. (2000) SAS/STAT User’s Guide. Version 9.1, SAS Institute, Cary.

[24] Winer, B.J. (1971) Statistical Principles in Experimental Design. 2nd Edition, McGraw-Hill Kogakusha Ltd., Tokyo.

[25] Holm, S. (1979) A Simple Sequentially Rejective Multiple Test Procedure. Scandinavian Journal of Statistics, 6, 6570.

[26] Kuusela, E., Khalili, H. and Nykanen-Kurki, P. (2004) Fertilisation, Seed Mixtures and Supplementary Feeding for Annual Legume-Grass-Cereal Pastures in Organic Milk Production Systems. Livestock Production Science, 85, 113127. http://dx.doi.org/10.1016/S0301-6226(03)00139-8

[27] Bow, J.R., Muir, J.P., Weindorf, D.C., Rosiere, R.E. and Butler, T.J. (2008) Integration of Cool Season Annual Legumes and Dairy Manure Compost with Switchgrass. Crop Science, 48, 1621-1628. http://dx.doi.org/10.2135/cropsci2007.12.0697

[28] El-Karamany, M.F., Bahr, A.A. and Tawfic, M.M. (2009) Forage Mixture Potential of Berseem Clover (Trifolium alexandrinum) with Triticale ( $X$ triticosecale wittmack) or Barley (Hordeum vulgare L.). Bulletin of the National Research, 34, 175-185.

[29] El-Karamany, M.F., Elwea, T.A. and Bakry, B.A. (2012) Effect of Mixture Rates on Forage Mixture of Egyptian Clover (Trifolium alexandrinum) with Triticale ( $X$ triticosecale wittmack) under Newly Reclaimed Sandy Soil. Australian Journal of Basic and Applied Research, 6, 40-44.

[30] Berry, P.M., Sylvester-Bradley, R., Philipps, L., Hatch, D.J., Cuttle, S.P., Rayns, F.W. and Gosling, P. (2002) Is the Productivity of Organic Farms Restricted by the Supply of Available Nitrogen? Soil Use and Management, 18, 248255. http://dx.doi.org/10.1079/SUM2002129

[31] Butler, T.J. and Muir, J.P. (2006) Dairy Manure Compost Improves Soil and Increases Tall Wheatgrass Yield. Agronomy Journal, 98, 1090-1096. http://dx.doi.org/10.2134/agronj2005.0348

[32] Mays, D.A., Terman, G.L. and Duggan, J.C. (1973) Municipal Compost: Effects on Crop Yields and Soil Properties. 
Journal of Environmental Quality, 2, 89-92. http://dx.doi.org/10.2134/jeq1973.00472425000200010011x

[33] Zheljazkov, V.D., Astatkie, T., Caldwell, C.D., MacLeod, J. and Grimmett, M. (2006) Compost, Manure, and Gypsum Application to Timothy/Red Clover Forage. Journal of Environmental Quality, 35, 2410-2418. http://dx.doi.org/10.2134/jeq2005.0322

[34] Parkinson, R.J., Fuller, M.P. and Groenhof, A.C. (1999) An Evaluation of Greenwaste Compost for the Production of Forage Maize (Zea mays L.). Compost Science and Utilization, 7, 72-80. http://dx.doi.org/10.1080/1065657X.1999.10701955

[35] Yolcu, H., Seker, H., Mkerim, G., Lithourgidis, A. and Gunes, A. (2011) Application of Cattle Manure, Zeolite and Leonardite Improves Hay Yield and Quality of Annual Ryegrass (Lolium multiflorum Lam.) under Semiarid Conditions. Australian Journal of Crop Science, 5, 926-931.

[36] Waldo, D.R. and Jorgensen, N.A. (1981) Forages for High Animal Production: Nutritional Factors and Effects of Conservation. Journal of Dairy Science, 64, 1207-1229. http://dx.doi.org/10.3168/jds.S0022-0302(81)82697-5

[37] Kanayama-Phiri, G.T., Raguse, C.A. and Taggard, K.L. (1990) Response of a Perennial Grass-Legume Mixture to Applied Nitrogen and Differing Soil Textures. Agronomy Journal, 82, 488-495. http://dx.doi.org/10.2134/agronj1990.00021962008200030009x

[38] Shareif, A.E., Attia, A.N., Leilah, A.A. and Abo El-Goud, S.A. (1996) Effect of Seeding Rates of Berseem-Ryegrass Mixtures and N-Fertilizer Levels on Yield and Quality of Forage. Proceedings of the 7th Conference of Agronomy, Mansoura, 9-10 September 1996, 589-599.

[39] Wood, C.W., Torbert, H.A. and Delaney, D.P. (1993) Poultry Litter as a Fertilizer for Bermudagrass Effects on Yield and Quality. Journal of Sustainable Agriculture, 3, 21-36. http://dx.doi.org/10.1300/J064v03n02_05

[40] Muir, J.P. (2002) Effect of Dairy Compost Application and Plant Maturity on Forage Kenaf Cultivar Fibre Concentration and in Sacco Disappearance. Crop Science, 42, 248-254. http://dx.doi.org/10.2135/cropsci2002.0248

[41] Haggag, M.E.H., Marei, Z.M. and El-Nahrawy, M.Z. (1995) Performance of Mixture of Ten Ryegrass Varieties with Egyptian Clover in Comparison with Pure Stand. Mansoura University Journal of Agricultural Sciences, 20, 45374547.

[42] Laidlaw, A.S. and Teuber, N. (2001) Temperate Forage Grass-Legume Mixtures: Advances and Perspectives. Proceedings of the 19th International Grassland Congress, Sao Paulo, 11-21 February 2001, 85-92. 